\title{
Geological themes in need of more attention
}

\author{
${ }^{1}$ Editor-in-Chief of Episodes, Department of Geology, Kangwon National University, Chuncheon 24341, Republic of Korea \\ ${ }^{2}$ Managing Editor of Episodes, Department of Geology, Kangwon National University, Chuncheon 24341, Republic of Korea \\ ${ }^{3}$ IUGS Secretary General, Department of Geological Sciences, California State University, Long Beach, CA 90840, USA \\ ${ }^{4}$ IUGS Publications Committee Chair, Department of Geology, University of Salamanca, 37008 Salamanca, Spain; *Corresponding author, \\ E-mail:mdp@usal.es
}

(Received: February 22, 2022; Revised accepted: February 28, 2022)

https://doi.org/10.18814/epiiugs/2022/022005

\section{Special Issues of the Past}

Episodes has published many excellent articles on relevant, provocative, and interesting geological themes in Special Issues (SIs). The IUGS Publications Committee and editorial team have endeavored to publish SIs regularly; however, it has remained inconsistent (Table 1). The themes of the Sis published in this journal include natural stones, asbestos, the geodynamic evolution of the Indian subcontinent, forensic geology, the great mineral fields of Africa, ophiolites, global heritage stone resources, catastrophic tsunamis, geology of the Oceania, and Nordic geoscience (see Table 1). Each SI contains 7 to 43 articles with a mean of 17. A Google Scholar search revealed that currently, each SI has been cited 12 to 1,099 times $($ mean $=252)$. Each article in the Sis has been cited 1.71 to 37.89 times. The SIs celebrating the International Geological Congress (IGC), held every four years, were a great success with regard to the citations by other studies.

\section{Interesting Geological Themes for Special Issue}

Many interesting geological themes have been overlooked as SIs in this journal. These include climate change, underground $\mathrm{CO}_{2}$ storage, earthquakes, geoparks, and microplastics in the soil and groundwater.

We are experiencing drastic changes in our climate at an unprecedented rate. Mitigation and adaptation strategies to manage these changes are essential. Therefore, understanding past periods of climate change recorded in the Earth's geology is critical (Lee et al., 2018; Lear et al., 2020). Thus, articles concerning the analyses of geological records relevant to climate change may draw interest from geologists and public communities. Carbon capture and storage (CCS) has been widely studied to manage and mitigate the negative effects of global warming (Bickle, 2009), and its commercial implementation is planned worldwide (Romanak and Dixon, 2022). The implementation of net-zerocarbon and carbon neutrality strategies in many countries has accelerated the practical application of CCS technologies (Bui et al., 2021). However, there are scientific and technological challenges that remain to be resolved, including public awareness (acceptance), siting of optimal locations, and the monitoring of $\mathrm{CO}_{2}$ leakage (Pianta et al., 2021). Articles addressing these social and technological challenges are very attractive.

Historically, earthquakes are themes that have been heavily researched (Valensise et al., 2003). There have been technological advancements in this field, and earthquake monitoring systems have been implemented worldwide, however, the risk to lives and infrastructure remains. The increasing urban population density exacerbates these risks (Celano

Table 1. Some of Special Issues published in Episodes

\begin{tabular}{|c|c|c|c|c|c|}
\hline Year & Vol(No) & Subjects (Theme) & $\begin{array}{l}\text { No. of Published } \\
\text { Items (A) }\end{array}$ & $\begin{array}{l}\text { Citation** } \\
\text { (B) }\end{array}$ & $\mathrm{A} / \mathrm{B}$ \\
\hline 2021 & $44(1)$ & Natural Stones & 8 & 23 & 2.88 \\
\hline 2020 & $43(3)$ & Asbestos & 7 & 12 & 1.71 \\
\hline 2020 & $43(1)^{*}$ & Geodynamic Evolution of the Indian Subcontinent - Hadean to Recent & 43 & 272 & 6.33 \\
\hline 2017 & $40(2)$ & Forensic Geology & 10 & 81 & 8.10 \\
\hline 2016 & $39(2)^{*}$ & The Great Mineral Fields of Africa & 17 & 294 & 17.29 \\
\hline 2015 & $38(4)$ & Ophiolites: Mantle Sources, Melt Evolution and Emplacement Mechanisms & 8 & 265 & 33.13 \\
\hline 2015 & $38(2)$ & Global Heritage Stone Resource: An Update & 9 & 94 & 10.44 \\
\hline 2014 & $37(4)$ & Towards More Effective Risk Reduction: Catastrophic Tsunami & 15 & 129 & 8.60 \\
\hline 2012 & $35(1)^{*}$ & Geology in the Oceania Region & 29 & 1,099 & 37.89 \\
\hline 2008 & $31(1)^{*}$ & Nordic Geoscience & 26 & $\mathrm{NC}^{* * *}$ & $\mathrm{NC}$ \\
\hline
\end{tabular}

*Special issue for the International Geological Congress (IGC)

**Total number of citation by other studies (searched using Google scholar, as of February 4, 2022)

***Not computed 


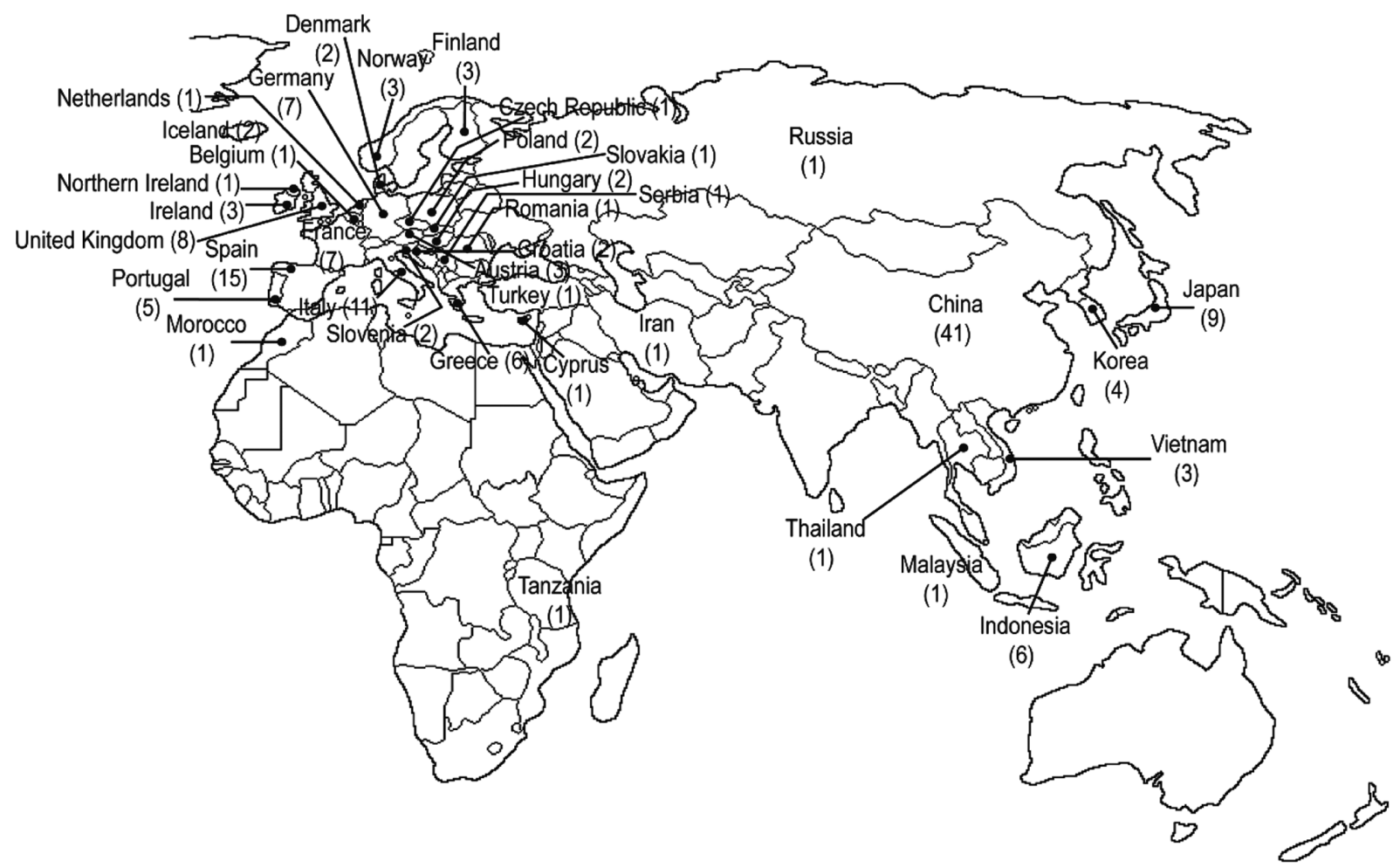

Figure 1. Distribution of Global Geoparks (GGPs) in the world with the number of GGPs in each country. The figure was modified from a photo taken at the Hantangang Global Geopark in Korea.

and Dolsek, 2021). As a result of numerous studies involving advanced monitoring systems, our understanding of earthquakes has enhanced significantly. However, there are still considerable gaps in our understanding of their developmental mechanisms and precursors. Recently, public concern has arisen regarding induced seismicity involved in enhanced geothermal systems and the hydrofracturing of shale gas (Lee et al., 2016). Timely SIs covering natural earthquakes and induced seismicity may be beneficial to the IUGS community.

Geoparks are single, unified areas that advance the protection and use of geological heritage sites sustainably while promoting the economic well-being of the people who live in these areas (Mc Keever and Zouros, 2005). Both global and national geoparks exist, and as of 2021, there are 169 UNESCO global geoparks in 44 countries (UGGP, 2022; Fig. 1). These geoparks attracting increasing interest worldwide. Designating national and global geoparks attracts many visitors, promotes the local economy, draws conservation efforts, and brings investment from central and provincial governments (Henriques and Brilha, 2017; Kim and Lim, 2019; Cho et al., 2021). To obtain and sustain the status of national and global geoparks, various efforts, including geological researches and managerial measures by governments, are essential. Thus, special articles dealing with geoparks will attract attention from geoscientists and governmental officials.

Plastic particles less than $5 \mathrm{~mm}$ in length, termed microplastics, are considered contaminants of emerging concern found in marine and freshwater environments, and are attracting interest from researchers and the public (Chia et al., 2021; Lee et al., 2021). Reports on the risks microplastics pose to human and ecosystem health are increasing, and public grievances are growing since studies have revealed that microplastics are often contained in drinking water and commonplace prod- ucts such as fruits and vegetables, toothpaste, cosmetics, and clothing (Kim and Lee, 2020; Rahman et al., 2021; Senathirajah et al., 2021). Studies have shown that microplastics are present in inland soil and groundwater (Cha and Lee, 2021; Kim et al., 2021). However, few have focused on the occurrence, distribution, fate, and transport of microplastics in aquifers, particularly from a hydrogeological perspective (Jeong and Lee, 2021). Without a detailed examination of the relevant geology and hydrogeology, a reliable understanding of microplastic distribution and transport in groundwater cannot be achieved.

In this regard, we await proposals for SIs concerning interesting and provocative themes, including those mentioned above. Proposals for SIs will be considered if they are agreed with the potential guest editors for at least one year in advance of its publication if approved. The submission must fit within approximately 75 printed pages (six to eight articles). Contributors must secure funds to support the expanded issues. No guest editor can author or co-author more than one article on their SI except for an editorial. The proposal should include the SI's title, a list of potential articles and their outlines, the authors and their affiliations, a clear motivation, the proposal goals, and submission and review timelines. Proceedings or contributions originating from a meeting or conference will not be published. SIs should focus on a single geological theme. There should be cohesion amongst the themes and a primary focus in each issue. All studies should be of broad international interest. The acceptance or rejection of a proposal depends entirely on the evaluation by the IUGS Publications Committee. All proposals must be submitted to the Editor-in-Chief of Episodes for evaluation. 


\section{References}

Bickle, M.J., 2009, Geological carbon storage. Nature Geoscience, v. 2, pp. 815-818.

Bui, M., Gazzani, M., Pozo, C., Puxty, G.D., and Soltani, S.M., 2021, Editorial: The role of carbon capture and storages in a net-zero carbon future. Frontiers in Energy Research, v. 9, 733968.

Celano, F. and Dolsek, M., 2021, Fatality risk estimation for industrialized urban areas considering multi-hazard domino effects triggered by earthquakes. Reliability Engineering \& System Safety, v. 206, 107287.

Chia, R.W., Lee, J.Y., Kim, H., and Jang, J., 2021, Microplastic pollution in soil and groundwater: a review. Environmental Chemistry Letters, v. 19, pp. 4211-4224.

Cha, J. and Lee, J.Y., 2021, Occurrence and distribution of microplastics in groundwater of a heavy agricultural area of Korea. AGU Fall Meeting, Abstract No. H15J-1154.

Cho, H., Kim, J.S., Kang, H.C., Park, J.W., Shin, S., Chae, Y.U., Ha, S., Kim, H.S., and Lim, H.S., 2021, Geological values of the Ueumdo geosite in the Hwaseong Geopark, Korea and its application to geo-education. Journal of the Geological Society of Korea, v. 57, pp. 257-273.

Henriques, M.H. and Brilha, J., 2017, UNESCO Global Geoparks: A strategy towards global understanding and sustainability. Episodes, v. 40, pp. 349-355.

Jeong, E. and Lee, J.Y., 2021, Comment on "Hazardous microplastic characteristic and its role as a vector of heavy metal in groundwater and surface water of coastal south India". Journal of Hazardous Materials, v. 421, 126693.

Kaown, D., Lee, K.K., Kim, J., Woo, J.U., Lee, S., Park, I.W., Lee, D., Lee, J.Y., Kim, H., Ge, S., and Yeo, I.W., 2021, Earthquakes and very deep groundwater perturbation mutually induced. Scientific Reports, v. 11, 13632.

Kim, H. and Lee, J.Y., 2020, Emerging concerns about microplastic pollution on groundwater in South Korea. Sustainability, v. 12, 5275.

Kim, H.S. and Lim, C., 2019, Developing a geologic 3D panoramic virtual geological field trip for Mudeung UNESCO global geoparks, South Korea. Episodes, v. 42, pp. 235-244.

Kim, Y.I., Jeon, E., and Lee, J.Y., 2021, Seasonal distribution of microplastics in groundwater of eastern Jeju, Korea. AGU Fall Meeting, Abstract No. H15J-1155.

Lear, C.H., Anand, P., Blenkinsop, T., Foster, G.L., Gagen, M., Hoogak- ker, B., Larter, R.D., Lunt, D.J., Nicholas McCave, I., McClymont, E., Pancost, R.D., Rickaby, R.E.M., Schultz, D.M., Summerhayes, C., Williams, C.J.R., and Zalasiewicz, J., 2020, Geological Society of London Scientific Statement: what the geological record tells us about our present and future climate. Journal of the Geological Society, v. 178, pp. 2020-239.

Lee, Y. and Jayakumar, R., 2021, Economic impact of UNESCO Global Geoparks on local communities: Comparative analysis of three UNESCO Global Geoparks in Asia. International Journal of Geoheritage and Parks, v. 9, pp. 189-198.

Lee, J.R., Candy, I., and Haslam, R., 2018, The Neogene and Quaternary of England: land scape evolution, tectonics, climate change and their expression in the geological record. Proceedings of the Geologists' Association, v. 129, pp. 452-481.

Lee, J.Y., Cha, J., Jeong, E., and Kim, Y.I., 2021, Comment on "Spatial distribution of microplastic concentration around landfill sites and its potential risk on groundwater". Chemosphere, v. 284, 131376.

Lee, J.Y., Weingarten, M., and Ge, S., 2016, Induced seismicity: the potential hazard from shale gas development and $\mathrm{CO}_{2}$ geologic storage. Geosciences Journal, v. 20, pp. 137-148.

Mc Keever, P.J. and Zouros, N., 2005, Geoparks: Celebrating Earth heritage, sustaining local communities. Episodes, v. 28, pp. 274-278.

Pianta, S., Rinscheid, A, and Weber, E.U., 2021, Carbon capture and storage in the United States: perceptions, preferences, and lessons for policy. Energy Policy, v. 151, 112149.

Rahman, A., Sarkar, A., Yadav, O.P., Achari, G., and Slobodnik, J., 2021, Potential human health risks due to environmental exposure to nanoand microplastics and knowledge gaps: A scoping review. Science of The Total Environment, v. 757, 143872.

Romanak, K. and Dixon, T., 2022, $\mathrm{CO}_{2}$ storage guidelines and the science of monitoring: Achieving project success under the California Low Carbon Fuel Standard CCS Protocol and other global regulations. International Journal of Greenhouse Gas Control, v. 113, 103523.

Senathirajah, K., Attwood, S., Bhagwat, G., Carbery, M., Wilson, S., and Palanisami, T., 2021, Estimation of the mass of microplastics ingested - A pivotal first step towards human health risk assessment. Journal of Hazardous Materials, v. 404, 124004.

UNESCO Global Geoparks (UGGp), 2021, UNESCO Global Geoparks. https://en.unesco.org/global-geoparks [accessed 1 February 2022].

Valensise, G., Amato, A., Montone, P., and Pantosti, D., 2003, Earthquakes in Italy: past, present and future. Episodes, v. 26, pp. 245-249. 